\title{
Obtaining and Maintaining the Distribution of Natural Reference Materials for U- Pb Geochronology by LA-ICP-MS: Protocols and Future Perspectives
}

\author{
Guilherme Gonçalves ${ }^{1}$, Cristiano Lana ${ }^{2}$, Ricardo Scholz ${ }^{2}$, Ian Buick ${ }^{3}$ and Maristella Santos ${ }^{4}$ \\ ${ }^{1}$ Universidade de Brasília - UnB, Brasília, Distrito Federal, Brazil, ${ }^{2}$ Universidade Federal de Ouro Preto \\ - UFOP, Ouro Preto, Minas Gerais, Brazil, ${ }^{3}$ Stellenbosch University, Stellenbosch, Western Cape, South \\ Africa, ${ }^{4}$ Instituto Federal de Minas Gerais - IFMG, Congonhas, Minas Gerais, Brazil
}

Over the past few decades, the great increase in the use of high-spatial resolution techniques, such as Laser Ablation-Inductively Coupled Plasma-Mass Spectrometry (LA-ICP-MS), for geochronology had a great impact in constraining the timing and rates of geological processes. As most of these techniques, especially LA-ICP-MS, are destructive by nature, they require a constant supply of well-characterized reference materials (RMs) that are used for both calibration and quality control. As general features, an RM should be isotopically homogeneous, have moderate to high U contents (tens to hundreds of ppm), negligible initial (non-radiogenic) $\mathrm{Pb}$ contents $\left(\mathrm{Pb}_{\mathrm{c}}\right)$, and be available in large quantities of coarse-grained, gemquality crystals for distribution. It is also desirable to have a range of RMs of a given mineral with different chemical compositions (e.g., Th, $\sum$ REE) in order to facilitate the correction of matrix-dependant isotopic fractionation. In this sense, some of the Brazilian Ediacaran-Cambrian orogens (such as the Araçuaí and Borborema), related to Gondwana amalgamation, have proven to be ideal suppliers of such natural megacrysts due to their great number of gem-producing pegmatites and quartz veins. In the past, a number of RMs from this region have been proposed, both from pegmatites and hydrothermal quartz-veins. These include the Bananeira monazite [1], which has a ${ }^{207} \mathrm{~Pb} /{ }^{235} \mathrm{U}$ age of $507.7 \pm 1.3 \mathrm{Ma}(2 \mathrm{~s})$ and moderate Th contents $(\sim 6.0 \mathrm{wt} \%)$, the hydrothermal Diamantina monazite [2], with a ${ }^{206} \mathrm{~Pb} /{ }^{238} \mathrm{U}$ age of $495.26 \pm 0.56$ Ma (2s) and low-Th ( 0.11 wt\%), the alluvial/hydrothermal Datas xenotime [3], with ${ }^{206} \mathrm{~Pb} /{ }^{238} \mathrm{U}$ ages of $513.4 \pm 0.9$ and $515.4 \pm 0.8 \mathrm{Ma}(2 \mathrm{~s})$ and a total $\sum \mathrm{REE}$ (oxide) of $\sim 19.0 \mathrm{Wt} \%$, and the hydrothermal Antonio Pereira rutile [4], with ${ }^{206} \mathrm{~Pb} /{ }^{238} \mathrm{U}$ age of $499.4 \pm 1.1 \mathrm{Ma}$ and $\mathrm{U}$ contents of $\sim 45 \mathrm{ppm}$. Here, we present the strategy adopted for obtaining, characterizing, distributing and maintaining minerals to be used as natural RMs for U-Pb geochronology by LA-ICP-MS. Subsequently, U-Pb data on one new potential apatite RM will be introduced. Most of the time, sampling these megacrysts directly from the outcrop is not straightforward. For this reason, these samples were purchased from local gem-dealers in assortments between $100-300 \mathrm{~g}$. The gem-quality crystals were then mounted directly in epoxy discs or fragmented beforehand. Several different crystals were pre-screened for their relative homogeneity of the U-Pb system, where only the most promising were further characterized. It is not uncommon that some megacrysts had concordant U-Pb isotope compositions with low common-lead content while others, from the same assortment, were not. In other cases, only after observing the long-term reproducibility, it was possible to differentiate crystals with slightly different age groups (e.g., the Blue Berry zircon [5, 6]), probably representing real geological scatter. Subsequently, the original mount is split and each megacryst (or part of it), is placed in groups, stored in different petri dish, and receives a corresponding label. Only a few of the best crystal (or fragments) are further characterized, including by Isotope Dilution-Thermal Ionization Mass Spectrometry (ID-TIMS), that due to its higher precision, is the technique of choice in order to determine the sample's "true or accepted" values. The monazite and xenotime RMs above mentioned above have been distributed worldwide. At some point, the megacrysts that were analysed by ID-TIMS and were distributed to geochronology laboratories will be exhausted. After that, the other crystals/fragments from the petri dish that belongs to the ID-TIMS group can also be further tested and 
distributed. It is important to emphasize that even though nearly identical ages can be observed at the LAICP-MS precision (ca. 1-2 \%), each crystal will show at least some variation when individually tested by ID-TIMS. That is the case of the wide-accepted "Moacyr" monazite (of which the Bananeira RMs form a part, and which have distinctly different Sm-Nd isotope systematics [1]) and Madagascar apatite for which, over the years, multiple ages have been published, sometimes outside the uncertainty (at 2s) of each other [see 1,7]. This is also the case for the Datas xenotime, for which ID-TIMS U-Pb ages for individual crystals are not identical within analytical uncertainty [3]. The small but significant U-Pb age heterogeneity between individual crystals of some RMs emphasizes the importance of analysing at least two secondary (or quality control) RMs. If the calibration RM used has a slightly different age of the published value, this inaccuracy will propagate and will result in relatively younger or older ages for both the quality control that are used. New attempts are currently being made towards finding and evaluating other phosphate minerals, including monazite with higher Th contents and apatite, as additional RMs for $\mathrm{U}-\mathrm{Pb}$ geochronology. One of them is the Sumé apatite, from the Borborema orogen, a gem-quality, deep blue-coloured fluorapatite. Six crystals were evaluated. Preliminary results (LA-ICP-MS, more than 250 laser spots) obtained over several analytical sessions, showed the existence of two different age batches, one with ca. $570 \mathrm{Ma}$ (batch \#1) and the other with $600 \mathrm{Ma}$ (batch \#2). One crystal of the batch \#1 was selected for ID-TIMS analyses. Three different aliquots produced a $\mathrm{Pb}_{\mathrm{c}}$-corrected ${ }^{206} \mathrm{~Pb} /{ }^{238} \mathrm{U}$ weighted average age of $568 \pm 3 \mathrm{Ma}(2 \mathrm{~s}, \mathrm{MSWD}=2.2)$, that is within uncertainties of the lower precision LA-ICPMS estimates. New efforts are continuously being made towards obtaining more ID-TIMS data and investigating the reproducibility of the common-lead corrected/uncorrected $\mathrm{U}-\mathrm{Pb}$ ratios in addition to round-robin sessions in order to propose this material as a new reference material for the scientific community.

\section{References}

[1] Gonçalves G. O., Lana C., Scholz R., Buick I., Gerdes A., Kamo S. L., et al. (2016). An assessment of monazite from the Itambé pegmatite district for use as a U-Pb isotope reference material for microanalysis and implications for the origin of the "Moacyr" monazite. Chemical Geology, 424, 30-50. [2] Gonçalves G. O., Lana C., Scholz R., Buick I. S., Gerdes A., Kamo S. L., et al. (2018). The Diamantina monazite: a new low-Th reference material for microanalysis. Geostandards and Geoanalytical Research, 42(1), 25-47. [3] Vasconcelos A., Gonçalves G.O., Lana C., Buick I.S., Kamo S.L., Corfu F., et al. (2018). Characterization of xenotime from Datas (Brazil) as a potential reference material for in-situ U-Pb geochronology. Geochem. Geophys. Geosyst., 19(7), 2262-2282. [4] Santos M. M., Lana C., Scholz R., Buick I. S., Kamo S. L., Corfu F., and Queiroga G. (2020). LA-ICP-MS U-Pb dating of rutile associated with hydrothermal mineralization along the southern Araçuaí Belt, SE Brazil. Journal of South American Earth Sciences, 99, 102502. [5] Santos M. M., Lana C., Scholz R., Buick I. S., Schmitz M. D., Kamo S. L., et al. (2017). A new appraisal of Sri Lankan zircons as reference material for in situ U-Pb geochronology, REE analyses and Lu-Hf isotopic tracing. Geostandards and Geoanalytical Research, 41(3), 335-358. [6] Lana C., Farina F., Gerdes A., Alkmim A., Gonçalves G. O., and Jardim A. C. (2017). Characterization of zircon reference materials via high-precision U-Pb LA-MC-ICP-MS. Journal of Analytical Atomic Spectrometry, 32(10), 2011-2023. [7] Thomson S. N., Gehrels G. E., and Ruiz J. (2012). Routine low-damage apatite U-Pb dating using laser ablation-multicollector-ICPMS. Geochem. Geophys. Geosyst., 13(1), Q0AA21. 